\title{
Strategi Pemimpin Dalam Menciptakan Pemerintahan Madani: Kota Banda Aceh Provinsi Aceh
}

\author{
Siska Pratiwi ${ }^{1}$, Masduki ${ }^{2}$ \\ ${ }^{1}$ Prince of Songkhla University, Thailand \\ ${ }^{2}$ Universitas Islam Negeri Sultan Syarif Kasim Riau \\ Email: Siskapratiwi2708@gmail.com
}

\begin{abstract}
This research is a qualitative research. This study aims to determine how the strategy of leaders in Banda Aceh in creating civilian leadership. Interview and observation are the main methods of data collection. Qualitative descriptive analysis is used as a method of analysis. The subjects of this research were the Mayor of Banda Aceh, the Head of Social Religion of Banda Aceh, the Chairperson of Banda Aceh (DPRK), the Head of the Da'wah Division of the Islamic Sharia Service, 1 traditional leader, and 1 person from a community. The results of this study indicate that Islamic leadership is a solution to the leadership crisis that occurs because Islamic leadership is focused on improving worldly goodness and achieving ukhrawi life. It can be concluded that the leaders in Banda Aceh apply several Islamic leadership principles, namely Asy-Shura, Muru'ah, AlJud Wa Fi Al-Haq, Ash-Shidq, I'daad Ash-Shaf Ats-Tsani Min Al-Qiyadah.
\end{abstract}

Keywords: Strategy, Leaders, Madani Government.

\begin{abstract}
Abstrak: Penelitian ini merupakan penelitian kualitatif. Penelitian ini bertujuan untuk mengetahui bagaimana strategi pemimpin di kota Banda Aceh dalam menciptakan kepemimpinan yang madani. Interview and observasi merupakan metode utama dalam pengumpulan data. Sedangkan Deskriptif kualitatif Analisis digunakan sebagai metode analisis. Subjek penelitan ini adalah Walikota Banda Aceh, Kasubag Sosial Keagamaan, Ketua DPRK Kota Banda Aceh, Kepala Bagian Bidang Dakwah Dinas Syari'ah Islam, 1 orang tokoh adat dan 1 orang masyarakat. Hasil dari penelitian ini menunjukkan bahwa kepemimpinan Islam merupakan solusi atas krisis kepemimpinan yang terjadi karena kepemimpinan Islam terfokus kepada perbaikan kebaikan duniawi dan meraih kehidupan ukhrawi. Dapat disimpulkan bahwa pemimpin kota Banda Aceh menerapkan Beberapa prinsip-prinsip kepemimpinan Islam, diantaranya yaitu: Asy-Syura, Muru'ah, Al-Jud Wa Fi Al-Haq, Ash-Shidq, I'daad Ash-Shaf Ats-Tsani Min Al-Qiyadah.
\end{abstract}

Kata Kunci: Strategi, Pemimpin, Pemerintahan Madani.

\section{Pendahuluan}

Dewasa ini banyak bermunculan teori-teori tentang kepemimpinan, hal ini menununjukkan pentingnya makna dari sebuah kepemimpinan di suatu kelompok maupun organisasi. Kepemimpinan menjadi bahasan penting karena merupakan hal yang kompleks yang melibatkan para pemimpin, para pengikut dan situasi, selain itu kepemimpinan dapat terjadi dimana saja dan kapanpun. Namun, ternyata teori tidak bersanding dengan kenyataan, bahkan kepemimpinan yang efektif menjadi bahan yang langka, khususnya di Indonesia dilihat dari praktek kepemimpinan yang selalu berakhir dengan kegagalan seperti banyaknya kasus yang terjadi, korupsi, masyarakat hidup melarat, yang kaya semakin kaya dan yang 
miskin semakin miskin bahkan tidak jarang juga seorang pemimpin yang mengakhiri kepemimpinannya di penjara. Praktek-praktek kepemimpinan saat ini menjadikan krisis hasil yang efektif, seharusnya memberikan kontribusi besar dalam perkembangan kehidupan manusia, namun mulai menjadi ricuh oleh maraknya praktek kepemimpinan yang tidak sehat dan berdampak buruk bagi perkembangan suatu instansi ataupun lembaga. Untuk mengatasi kasus-kasus yang terjadi, perlu adanya praktek kepemimpinan yang kembali kepada praktek kepemimpinan Islam yang bersumber kepada al-Qur'an dan Hadist. Karena dengan diterapkannya kepemimpinan Islam akan mampu memberikan perubahan terhadap praktek kepemimpinan di masa kini. Sehingga akan menciptakan kepemimpinan yang mengarah kepada "Rahmatan lil a'lamiin".

Saat ini, daerah yang berani menerapkan prinsip-prinsip kepemimpinan Islam adalah kota Banda Aceh, Banda Aceh dengan keistimewaan telah mencoba menerapkan nilai-nilai keislaman. Banda Aceh merupakan daerah pertama yang sejak lahir sudah mempraktekkan ajaran Islam dan menerapkan kepemimpinan Islam di wilayah Asia Tenggara dan Kepulauan Nusantara. Islam di Banda Aceh saat ini bukan sekedar label tetapi sudah direalisasikan pada sistem pemerintahan bahkan telah masuk ke dalam kehidupan masyarakat. Hal ini dibuktikan dari budaya dan undang-undang yang terdapat di Kota Banda Aceh telah mengarah kepada perundang-undangan Islam dengan Konsekuensi pelanggaran sesuai dengan hukum Islam. Setelah rentang waktu empat puluh tahun, pemerintah mengeluarkan Undang-Undang Nomor 44 tahun 1999. Undang-Undang ini sebagai kontruksi kuat bagi Aceh untuk menerapan pemberlakuan Syari'at Islam secara penuh tanpa perlu ikut campur tangan pemerintah, secara Yuridis Formal diberikan kewenangan yang luas untuk mengatur hukum Syari'at (Abdul Gani Isa, 2013).

Menindak lanjuti UU Nomor 44 tahun 1999 dan UU Nomor 18 Tahun 2001, dan dalam upaya mempercepat pelaksanaan Syari'at Islam sesuai tuntutan masyarakat, pemerintah Aceh telah mengeluarkan sejumlah Perda dan Qanun Syari'ah, seperti Perda Nomor 5 Tahun 2000 tentang pelaksanaan Syari'at Islam, Qanun Nomor 10 Tahun 2002 tentang Mahkamah Syar"iyah, Qanun Nomor 11 Tahun 2002 tentang pelaksanaan Syari'at bidang aqidah, ibadah dan syi'ar Islam, Qanun Nomor 12 Tahun 2003 tentang Khamar dan sejenisnya, Qanun Nomor 13 tentang Maisir (perjudian), Qanun Nomor 14 Tahun 2003 tentang Khalwat (mesum), Qanun Nomor 7 Tahun 2004 tentang Pengelolaan Zakat dan lain-lain (Abdul Gani Isa, 2013). Berangkat dari latar belakang tersebut penulis ingin melakukan analisa lebih lanjut tentang Kepemimpinan Islam dengan Judul "Strategy Pemimpin Dalam Menciptakan Pemerintahan Madani Kota Banda Aceh Provinsi Aceh"

\section{Metode Penelitian}

Penelitian ini merupakan penelitian kualitatif. Penelitian ini bertempat di kota Banda Aceh, Provinsi Aceh. Pengambilan data dalam penelitian ini dikelompokkan kedalam sumber data primer dan sekunder, Sumber data primer yaitu sumber data yang langsung dikumpulkan oleh peneliti dari sumber pertamanya terkait dengan penelitian ini, data primer didapatkan dengan wawancara dan survei langsung kepada para informan penelitian. Sedangkan, Sumber data sekunder adalah data yang diperoleh atau dikumpulkan oleh orang 
yang melakukan penelitian dari sumber-sumber yang telah ada. Data ini diperoleh dari perpustakaan atau dari laporan-laporan penelitan terdahulu. Data yang disajikan berupa wawancara dan observasi serta didukung dengan dokumentasi terkait untuk mendapatkan data dan informasi mengenai strategi pemimpin dalam menciptakan kepemimpinan Madani di Kota Banda Aceh. Selain itu, wawancara dilakukan dengan mengajukan beberapa pertanyaan mengenai terkait dengan penelitian yang sedang diadakan.

Adapun yang menjadi subjek (informan penelitian) dalam penelitian ini adalah Pejabat Pemerintahan yakni, Walikota Kota Banda Aceh, Kasubag Sosial keagamaan bagian keistimewaan dan kesrah Kota Banda Aceh, ketua DPRK Kota Banda Aceh, kepala bagian bidang dakwah Dinas Syari'ah Islam Kota Banda Aceh, 1 orang tokoh adat Kota Banda Aceh dan 1 orang masyarakat Kota Banda Aceh. Sampel dalam penelitian menggunakan teknik purposive sampling. Penggunaan teknik ini mempunyai tujuan yang dilakukan dengan sengaja dan dapat mewakili karakteristik populasi. Teknik analisis data dalam penelitian ini menggunakan teknik analisis deskriptif kualitatif. Deskriptif ini dilakukan dengan cara meyusun dan mengelompokkan data yang ada, sehingga memberikan gambaran nyata terhadap informan.

\section{Hasil dan pembahasan}

Dalam setiap aktivitas kepemimpinan di Banda Aceh, Asy-Syura merupakan salah satu prinsip utama yang harus diterapkan, karena dengan adanya prinsip ini akan mejadikan daerah yang aman, tertib, damai dan tidak bersifat diktator. Dalam penerapan prinsip AsySyura secara Islami pemerintah Kota Banda Aceh memberikan peluang yang sangat besar kepada seluruh masyarakat untuk menyampaikan aspirasi tanpa membedakan golongan, suku dan ras. Penyampaian aspirasi bisa dilakukan secara langsung dan bisa melalui media sosial sebagai wadah yang memudahkan masyarakat untuk menyampaikan aspirasi. Responden 1 menyebutkan bahwa "Sifat toleransi diperdayakan oleh pemerintah dalam penerapan prinsip Asy-Syura ini”(Responden 1, Wawancara, 15 Maret 2017)

Selain itu, pemerintah Kota Banda Aceh juga melakukan musyawarah yang sesuai dengan tuntunan syari'at Islam yang melibatkan semua komponen masyarakat dalam pengambilan keputusan. Sebagaimana kasus meusum di Gampong Alue Naga Kota Banda Aceh, dimana pemerintah tidak memutuskan hukum namun memberikan wewenang tersebut kepada masyarakat gampong dalam mengambil kebijakan, aturan tersebut sudah diatur dalam Reusam Gampong atau aturan Gampong. Namun, apabila masyarakat gampong tidak mengambil kebijakan baru pemerintah Kota melalui Wilayatul Hisbah (WH) yang bertindak. Responden 2 menjelaskan bahwa"pemimpin kota Banda Aceh selalu melakukan musyawarah dengan tokoh masyarakat dalam kasus yang berhubungan dengan masyarakat demi selamat dari penyesalan akibat kesewenang-wenangan dalam menerapkan pendapatnya yang jelasjelas salah" (Responden 2, Wawancara, 17 Maret 2017)

Sebagai daerah yang benar-benar sudah menerapkan kepemimpinan Islam, pemimpin Kota Banda Aceh tidak menginginkan adanya perselisihan dalam segi apapun, karena mengingat Kota Banda Aceh merupakan kota Madani yang harus menjaga ketentraman, kesejahteraan dan kedamaian. 
Responden 3 juga menjelaskan"Hal ini ternyata perlahan telah berhasil dikontrol oleh pemimpin Banda Aceh dari tindakan-tindakan yang telah beliau lakukan. Karena pemimpin Kota Banda Aceh tidak pernah memperlihatkan sikap buruk ketika ada sesuatu yang tidak sesuai dengan dirinya dan hal ini juga yang dicontohkan kepada jajaran pemerintah dan masyarakat Kota Banda Aceh Sebagaimana setiap permasalahan yang dihadapi oleh bawahan, Walikota selalu menyelesaikannya dengan lemah lembut dan dengan sikap yang tenang sehingga tidak terjadi pergeseran dan rasa tersinggung antar bawahan" (Responden 3, Wawancara, 17 Maret 2016).

Selain itu, Ternyata pemimpin serta jajaran pemerintahan selalu mencoba menjaga kehormatan diri dalam proses kepemimpinannya. Hal ini dibuktikan dari hubungan antara pemimpin dengan bawahan yang saling menjaga keharmonisan dan saling membimbing serta saling menghormati satu dengan yang lain, baik atasan dengan bawahan maupun membimbing akhlak yang lebih baik. Reseponden 4 menyebutkan bahwa "Walikota sangat akrab, baik dan menghargai bawahannya" (Responden 4, Wawancara, 18 Maret 2016)

Hal ini memperlihatkan bahwa muru'ah dalam pemerintahan Kota Banda Aceh sudah terjalankan dengan baik,. Banyak hal yang telah dilakukan pemimpin Kota Banda Aceh dalam mewujudkan kedermawanannya kepada masyarakat maupun jajaran pemerintah, diantaranya menyediakan waktu sepenuhnya untuk masyarakatnya baik jam kerja maupun bukan jam kerja. Selain itu pemimpin juga memperagakan bahwa pemimpin layaknya seorang pelayan untuk rakyatnya, yang melayani dengan penuh keihklasan, kesabaran menanggung beban serta cacian dari rakyat. Itulah hal-hal yang telah dikorbankan selama masa kepemimpinannya. Bahkan hampir disetiap kegiatan formal maupun sosial pemimpin Kota Banda Aceh serta jajarannya ikut serta dan turun secara langsung dalam kegiatan tersebut. Responden 3 menyampaikan "karena kedermawanan dan kemurahan hatinya tidak ada masyarakat Kota Banda Aceh yang belum bersalaman dengan Illiza"(Responden 3, Wawancara, 17 Maret 2017).

Seperti yang beliau lakukan kepada masyarakat, juga beliau wujudkan kepada jajaran pemerintahan, anggota maupun bawahannya. Seperti memberikan hak yang wajar kepada jajaran, memberikan kehormatan serta menghargai jajaran dengan penghargaan yang tinggi, serta ikut bergabung bersama anggota dalam kegiatan-kegiatan tertentu, selain itu juga mengadakan kegiatan-kegiatan hiburan bersama karyawannya dalam rangka mempererat silaturrahmi. Perwujudan kedermawanan dan kemurahan hati pemimpin juga diwujudkan melalui pemberian materiil kepada pegawainya dalam bentuk penambahan tunjangan dan jaminan bagi pegawai dan masyarakatnya.

Responden 2 "Selain itu, pemerintah Kota Banda Aceh juga membuat sebuah program Banda Aceh berkurban yang wajib diikuti oleh seluruh pemimpin-pemimpin yang terdapat di Kota Banda Aceh dalam rangka berbagi kepada masyarakat-masyarakat yang kurang mampu, mengadakan hari Yatim untuk seluruh anak yatim yang terdapat di Kota Banda Aceh dan ikut berpartisipasi dalam membantu beban Palestina" (Responden 2, Wawancara, 17 Maret 2017).

Berdasalkan hasil penelitian yang didapat dalam perihal pemerintahan pemimpin kota Banda Aceh sudah menerapkan sistem yang sangat jujur dan sangat terbuka terhadap jajarannya serta masyarakatnya. Responden 1 memperkuat bahwa "Kota Banda aceh dalam 
hal transparansi dana setiap tahunnya mendapatkan prediket WPT (Wajar Tanpa Pengecualian)" (Responden 1, Wawancara, 15 Maret 2017).

Karena semua dana yang masuk dan keluar lansung dilaporkan dan juga di masukkan kedalam Web Kota Banda Aceh dan bisa dipantau oleh siapapun yang ingin mengetahui tentang pendanaan kota Banda Aceh. Selain itu, menurut Responden 4 "Namun, permasalahan kejujuran ini tergantung kepada pribadi setiap orang, apalagi $100 \%$ dari kepegawaian Kota Banda Aceh beragama Islam, Karena kejujuran merupakan salah satu aturan di dalam Islam maka semua umat Islam wajib menjalankannya"(Responden 4, Wawancara, 18 Maret 2017).

Selain itu, yang paling unik, walikota Banda Aceh mengembangkan pemerintahan Madani yang wajib untuk diaplikasikan baik oleh jajaran pemerintahan maupun masyarakat sekitar. Tapi aturan yang wajib ini lebih terfokus kepada pemerintahan yaitu dalam menjalankan program dan janji terhadap rakyat. Namun seperti pada bagian-bagian sebelumnya pemimpin Banda Aceh lebih mengutamakan kepentingan rakyat, sehingga selalu mencoba mewujudkan pembangunan-pembangunan baik dalam bentuk fisik maupun mental sebagai bukti janji serta visi dan misi yang telah diucapkan kepada rakyat. Ternyata, Kota Banda Aceh yang terkenal dengan kota Madani yang menerapkan kepemimpinan Islam juga mempunyai sanksi bagi jajaran yang melakukan tindakan penipuan sesuai dengan hukum nasional, yang tidak menerapkan prinsip kejujuran dalam roda pemerintahan, yaitu diawal akan diberi peringatan dan kemudian jika masih diulangi berkata yang tidak benar akan di mutasi dari jabatan, tetapi hal ini masih terfokus kepada jajaran pemerintahan.

Responden 2 menyampaikan "pemimpin Banda Aceh merupakan pemimpin yang aktif dalam segala bidang, hal itu dibuktikan dari prestasi-prestasi yang telah didapatkannya. Tidak hanya itu ternyata pemimpin Banda Aceh adalah pemimpin yang mempunyai keikutsertaan dalam menjalankan roda pemerintahan ditengah-tengah masyarakat dan selalu ikut menghadiri agenda-agenda baik dari pemerintahan maupun masyarakat baik agenda besar maupun agenda kecil'(Responden 1, Wawancara, 17 Maret 2017).

Pemimpin kota Banda Aceh ikut serta dalam menghadiri kegiatan ODOJ (One Day One Juz) yang diadakan oleh pemuda Kota Banda Aceh, dakwah Jum'atan, bakti sosial, hari anak Nasional dan kegiatan lainnya. Terjun lansung adalah caranya untuk memahami masyarakat layaknya seperti apa yang telah dilakukan oleh Rasulullah.. Bahkan dalam keadaan apapun dan situasi apapun Illyza terjun secara langsung untuk membantu. Bahkan dikatakan bahwa hampir seluruh masyarakat Kota Banda Aceh sudah bersalaman dengan wali kotanya.

Tidak hanya itu, Pada masa sekarang ternyata Banda Aceh adalah satu-satu daerah yang sudah mempunyai generasi-generasi Islam yang siap untuk dijadikan pemimpin. Karena dalam hal ini banyak kegiatan-kegiatan yang mengarahkan generasi-genarasi Islam untuk siap memimpin dan dipimpin. Sehingga tidak akan terjadi kekosongan kepemimpinan Islami di Kota Banda Aceh. Dalam mewujudkan generasi-generasi penerus Islami, walikota Banda Aceh beserta jajarannya melaksanakan berbagai kegiatan guna mendukung terwujudnya generasi-generasi Islami yang siap memimpin dimasa yang akan datang dengan melanjutkan kepemimpinan Islam yang telah di terapkan. Kegiatannya dalam bentuk FASI (festival anak shaleh), juga melaksanakan MTQ dan LPTQ, dan berupa pelatihan kepemimpinan yang 
dinamai dengan ESQ yang bertujuan untuk mendidik jiwa-jiwa pemuda menjadi jiwa-jiwa muslim yang siap menjadi pemimpin Islami.

Responden "Pemerintah juga bekerjasama dengan Dinas Syariah Islam melalui program penyelamatan generasi muda setiap hari Jum'at guna membentuk jiwa-jiwa Islami yang bisa menjadi generasi pemimpin Islam”.

Selain itu, juga generasi pemimpin Islami juga diwujudkan melalui jalur pendidikan di jenjang perkuliahan dengan memasukkan pengkajian tentang kepemimpinan islami yang didukung langsung oleh pemerintah.

Setelah data yang diperoleh melalui wawancara, observasi dan dokumentasidokumentasi disajikan, maka selanjutnya dianalisis. Teknis analisis yang digunakan dalam penelitian ini adalah teknis secara kualitatif, dari data yang diperoleh, pemimpin Kota Banda aceh menerapkan beberapa prinsip-prinsip kepemimpinan Islam untuk menciptakan pemerintahan Madani di Kota Banda Aceh, diantaranya :

\section{Asy-Syura (Musyawarah)}

Bermusyawarah merupakan salah satu faktor yang harus diaplikasikan dalam proses kepemimpinan, karena dengan adanya Asy-Syura mampu menciptakan kondisi aman, tertib dan aman. Semua aspirasi baik dari pemerintah maupun dari masyarakat bisa dibicarakan melalui musyawarah. Tanpa adanya prinsip Asy-Syura maka proses kepemimpinan akan berjalan dengan lancar. Di dalam prinsip ini terdapat sebuah proses pengambilan keputusan yang diambil dari kesepakatan bersama dan tidak merugikan satu sama lainnya. Prinsip ini harus benar-benar dipertahankan dan benar-benar diaplikasikan sesuai dengan perintah yang telah dijelaskan didalam Islam. Gemar bermusyawarah merupakan sesuatu sifat yang harus dimiliki oleh setiap pemimpin, baik dalam permasalahan umum, seperti penataan permasalahan umat atau dalam permasalahan khusus yang berkenaan dengan perorangan atau masalah pribadi.

Setelah mendengar berbagai jawaban dan penjelasan dari para responden yang menjadi narasumber penulis dalam penelitian ini, penulis berpendapat bahwa pelaksanaan prinsip Asy-Syura ini sudah terlaksana dengan baik dan cukup efektif oleh pemerintah Kota Banda Aceh bekerjasama dengan masyarakat Kota Banda Aceh. Terlihat dari kondisi yang aman di Kota Banda Aceh, tentram dan keamanan yang berjalan lancar setiap harinya, dan jarang sekali terdengar adanya demontrasi dari masyarakat dan pelajar-pelajar yang ada di Kota Banda Aceh, karena semua aspirasinya di respon dan dimusyawarahkan dengan cepat secara bersama.

Sesuai dengan analisa di atas, berhubungan juga dengan dikatakan oleh Syaitut bahwa Asy-Syura merupakan dasar kedua negara Islam, menurutnya Asy-Syura dapat dipastikan sebagai dasar hukum terbaik, yang dengannya dapat diciptakan pendapat yang akurat (Muhammad Iqbal dan Amin Husein Nasution, 2014). Dari analisa dan didukung oleh sebuah pendapat dari Syaitut maka dapat dikatakan bahwa Asy-Syura merupakan bagian yang sangat penting yang harus dimiliki oleh pemimpin, pegawai dan masyarakat untuk mewujudkan kesejahteraan secara adil melalui pengambilan keputusan bersama secara akurat. Tidak hanya itu, Ulama menjadi orang-orang pilihan untuk mendiskusikan pendpat-pendapat yang ada, karena Ulama di Aceh memiliki peras yang sangat besar dalam kehidupan, tidak hanya dalam 
kaitannya dengan persoalan keagamaan, tetapi tetapi juga menyangkut persoalan sosial kemasyarakatan, menjadi sosok yang sangat dihormati, bahkan mendapat kedudukan tertinggi dalam strata sosial masyarakat. Hampir dalam setiap persoalan yang dipecahkan bersama, pendapat yang paling didengar adalah pendapat ulama. Ulama identik dengan posisi syeikh (Firdaus, 2010) dalam strata Arab awal kebangkitan Islam. Ketika Perang Aceh (18731905) melawan Belanda yang terjadi beberapa tahun silam, dimana pasukan Belanda untuk pertama kalinya memasuki pantai Kuala lue yang dipimpin oleh Mayjen Verpijick dengan pasukan yang besar dan persenjaataan yang lengkap.

Ulama pada saat itu berada digaris depan dan mampu menghadang tentara Belanda, meskipun senjata rakyat Aceh pada sangat itu sangat minim dan sederhana namun berkat semangat Jihat para ulama telah menunjukkan hasil gemilang (Firdaus, 2010). Belanda berhasil dilumpuhkan dengan strategi musyawarah yang ditempuh para ulama pada waktu itu, Musyawarah yang dihadiri sekitar 500 orang dari berbagai unsur baik unsur dari kerajaan, maupun unsur dari rakyat biasa (Fitriani, 2016). Musyawarah tersebut dipimpin oleh Imum Lueng Bata dan Teugku Lamnga yang merupakan tokoh ulama setempat. Setelah para ulama memberi pendapat dan penjelasan yang ditinjau dari hukum Islam, hasil musyawarah pada waktu itu mencapat kesimpulan bahwa wajib melakukan perang sabil untuk mengusir Belanda.

\section{Muru'ah (Menjaga kehormatan diri)}

Selain Asy-Syura, prinsip Muru'ah juga merupakan bagian terpenting dalam penerapan kepemimpinan Islam. Karena dengan adanya penerapan prinsip Muru'ah ini dalam penyelenggaraan roda pemerintahan maka akan terbentuk kepemimpinan yang selalu menjaga keutuhan roda pemerintahannya. Muru'ah ini tidak hanya tergambar dalam tingkah laku atau terlihat dari akhlak yang baik saja, melainkan juga mengharuskan bertutur kata yang manis, baik. Muru'ah ini disebut dengan Muru'ah lisan yang harus diterapkan oleh pemimpin, kepegawaiannya, dan seluruh masyarakat Kota Banda Aceh, selain itu juga mengharuskan untuk mendermakan hartanya untuk jalan yang terpuji menurut akal, niat dan syara'. Muru'ah ini dinamai dengan muru'ah Harta, yang juga harus diterapkan oleh pemimpin, kepegawaian dan masyarakatnya. Sehingga jika di terapkan prinsip muru'ah ini maka akan menjaga persatuan antara pemimpin dengan jajarannya dan pemerintahan dengan masyarakat Kota Banda Aceh. Kepemimpinan Kota Banda Aceh sudah mengarah kepada pengaplikasikan prinsip Muru'ah. Hal ini terlihat dari hubungan antara pemimpin dengan bawahan yang begitu akrab dan juga pemimpin dengan masyarakat yang juga saling terbuka dan menghargai satu sama lainnya. Pemimpin Kota Banda Aceh merupakan salah satu pemimpin yang sangat disanjung dan dihormati oleh jajaran pemerintah serta masyarakatnya karena ketegasannya serta keteladanannya dalam menerapkan syari'ah Islam dan mengaplikasikan prinsip-prinsip kepemimpinan Islam dalam penyelenggaraan pemerintahannya. Selain itu, Sebagaimana setiap permasalahan yang dihadapi oleh bawahan, Walikota selalu menyelesaikannya dengan lemah lembut dan dengan sikap yang tenang sehingga tidak terjadi pergeseran dan rasa tersinggung antar bawahan. 
Ternyata pemimpin serta jajaran pemerintahan sudah mengarah kepada penerapan Muru'ah dalam proses kepemimpinannya. Hal ini dibuktikan dari hubungan antara pemimpin dengan bawahan yang saling menjaga keharmonisan dan saling membimbing serta saling menghormati satu dengan yang lain, baik atasan dengan bawahan maupun membimbing akhlak ke yang lebih baik. Hal inipun sesuai dengan konsep atau hal-hal yang harus diperhatikan dalam penerapan muru'ah yang dijelaskan didalam buku The Art of Leadership yaitu : muru'ah akhlak, muru'ah lisan, dan muru'ah harta (Muhammad Fathi, 2007). Maka didukung oleh teori yang dikemukakan di dalam buku tersebut dan berdasarkan analisa penulis bahwa prinsip Muru'ah ini sudah mengacu kepada penerapan yang efisiensi.

\section{Al-Jud Wa Fi Al-Haq (Kedermawanan dan kemurahan hati)}

Dermawan merupakan salah satu prinsip yang harus menjadi sebuah karakter dan tertanam di dalam diri seorang pemimpin dan seluruh jajaran pemerintahannya. Layaknya Rasulullah yang mempunyai sifat kedermawanan dan kemurahan hati yang sangat baik dalam berbagai aspek pemerintahan. Menurut analisa penulis dalam penerapan prinsip ini pemimpin Kota Banda Aceh sudah mulai berperan di pemerintahan Kota Banda Aceh dan masyarakat Kota Banda Aceh. Banyak hal yang telah dilakukan pemimpin Kota Banda Aceh dalam mewujudkan kedermawanannya di tengah-tengah masyarakat Kota Banda Aceh melalui program-program yang telah dirancang bersama, seperti: memberikan sumbangan kepada masyarakat dengan terjun ketengah-tengah masyarakat tanpa memperdulikan situasi dan kondisi disaat itu, menyediakan waktu untuk masyarakatnya baik jam kerja maupun tidak, rela menjadi pelayan terhadap masyarakatnya, memberikan hak yang wajar kepada jajaran, memberikan kehormatan serta menghargai jajaran dengan penghargaan yang tinggi, ikut bergabung bersama anggota dalam kegiatan-kegiatan tertentu dan masih banyak kedermawanan dan kemurahan hati yang telah dilakukannya, mengadakan program Banda Aceh berkurban yang diikuti oleh pemimpin-pemimpin yang terdapat di Kota Banda Aceh dan ikut berpartisipasi dalam membantu masalah yang terdapat di Palestina.

Bila menilik penjelasan di atas, keinginan terbesar pemerintahan Kota Banda Aceh adalah mewujudkan kesejahteraan secara merata dan membantu masyarakat dalam mengatasi permaslahan guna tercapainya kesejahteraan secara menyeluruh, sehingga kota yang tamadun akan dapat terealisasi sesuai dengan visi dan misi wali Kota Banda Aceh periode 2012-2017. Dalam piagam Madinahpun telah dijelaskan mengenai sikap saling membantu dan saling memberdayakan, sebagaimana yang di tuangkan dalam pasal 11 berbunyi "Sesungguhnya mukminin tidak boleh membiarkan orang yang berat menanggung utang diantara mereka tetapi membantunya dengan baik dalam pembayaran tebusan atau diat", hal ini sesuai yang tercantum dalam misi Kota Banda Aceh point ke 4 berbunyi "Menumbuhkan masyarakat yang berintelektualitas, sehat dan sejahtera, yang menguasai berbagai ilmu pengetahuan, teknologi, seni dan budaya" menumbuhkan sikap masyarakat dalam hal kesejahteraan, artinya dapat membantu masyarakat dalam berbagai macam kendala sehingga melahirkan kesejahteraan.

Selain itu juga dijelaskan di dalam buku The Art of Leadership bahwa fase-fase kedermawanan diantaranya : dermawan dengan jiwa, dermawan terhadap yang dipimpin, 
dermawan dalam memberikan waktu istirahat kepada pegawai, dermawan dengan ilmu dan kerendahan hatinya, dermawan terhadap kekuasaanya, dermawan terhadap badannya, dermawan dengan kehormatan, dermawan dengan kesabaran, dermawan dengan akhlak mulia, dan dermawan dengan sesuatu yang telah menjadi milik orang lain (Muhammad Fathi, 2007). Sesuai dengan analisa yang didukung oleh piagam Madinah dan fase-fase leadership yang dikemukakan di dalam buku The Art of Leadership dapat dikemukakan bahwa prinsip Muru'ah ini sudah mulai berjalan dengan baik, meskipun masih banyak kekurangan didalam penerapannya. Sesuai dengan piagam madinah pasal 23 yang berbunyi "apabila kamu berselisih tentang sesuatu, penyelesaiannya menurut (ketentuan) Allah Azza Wa Jalla dan (keputusan) Muhammad Saw (pemimpin)".

\section{Ash-Shidq (Kejujuran)}

Prinsip Ash-Shidq merupakan prinsip yang dianjurkan Islam dan akan menjadi salah satu faktor suksesnya sebuah kepemimpinan dalam pemerintahan. Jika prinsip kejujuran tidak diterapkan, maka akan terjadi penyelewangan kepemimpinan dalam berbagai aspek penyelenggaraan pemerintah. Menurut penulis, pemerintah Kota Banda Aceh merupakan daerah yang mengutamakan penerapan kejujuran yang tercermin pada diri Rasulullah. Setelah mendengar jawaban dan penjelasan dari narasumber yang menjadi informan penelitian penulis tentang penerepan prinsip-prinsip Kepemimpinan Islam, hal ini dibuktikan dari keterbukaan proses kepemimpinan kepada masyarakat Kota Banda Aceh dalam berbagai aspek, seperti halnya dalam pendanaan. Dalam hal ini tidak ada yang ditutupi, karena pemimpin Kota Banda Aceh selalu melakukan proses transparansi dana kepada jajaran dan masyarakatnya dengan cara membuat laporan pendanaan dan bisa lansung dipantau masyarakat melalui web Kota Banda Aceh bahkan Kota Banda Aceh setiap tahunnya selalu mendapatkan WTP (Wajar Tanpa Pengecualian).

\section{I'daad Ash-Shaf Ats-Tsani min Al-Qiyadah (Mempersiapkan Pemimpin Lapis Kedua dan Generasi Penerus)}

Menurut penulis, implementasi I'daad Ash-Shaf Ats-Tsani min Al-Qiyadah dalam pemerintahan Kota Banda Aceh lebih mengarah kepada kegiatan-kegiatan pembentukan pribadi-pribadi Islami, pribadi-pribadi yang tangguh yang siap menjadi generasi penerus Kota Banda Aceh dimasa yang akan datang. Hal ini dibuktikan dengan adanya berbagai kegiatan guna mendukung terwujudnya generasi-generasi Islami yang siap memimpin dimasa yang akan datang dengan melanjutkan kepemimpinan Islam yang telah diterapkan. Kegiatannya dalam bentuk FASI (festival anak sholeh), juga melaksanakan MTQ dan LPTQ, dan berupa pelatihan kepemimpinan yang dinamai dengan ISQ yang bertujuanuntuk mendidik jiwa-jiwa pemuda menjadi jiwa-jiwa muslim yang siap menjadi pemimpin Islami.

\section{Simpulan}

Setelah data disajikan dan dianalisis, dapat disimpulkan bahwa pemimpin kota Banda Aceh berupaya menciptakan pemerintahan Madani melalui penerapan kepemimpinan Islam. Sehingga terciptalah pemerintahan yang transparan dan mengutamakan rakyat dalam 
berbagai hal. Strategi-strategi yang yang dilakukan oleh pemimpin kota Banda Aceh mengarah kepada prinsip-prinsip kepemimpinan Islam. sehingga dapat disimpulkan bahwa pemimpin kota Banda Aceh telah berhasil menerapkan beberapa prinsip-prinsip kepemimpinan untuk menciptakan pemerintah yang Madani di Kota Banda Aceh. Meskipun belum diterapkan secara kaffah oleh masyarakat Kota Banda Aceh, namun kota Banda Aceh mengarah kepada penerapan kegiatan kepemerintahannya yang sesuai dengan kepemimpinan Islam yang berlandaskan Al-Qur'an dan Al-Hadist. Prinsip-prinsip kepemimpinan Islam yang saat ini juga masih dipegang teguh dan dilaksanakan dengan cara baik oleh pemimpin Kota Banda Aceh dan Pemerintah Kota Banda Aceh adalah : Asy-Syura (Musyawarah), Muru'ah (Menjaga Kehormatan Diri), Al-Jud Wa Fi Al-Haq (Kedermawanan dan kemurahan hati), Ash-Shidq (Kejujuran), I'daad Ash-Shaf Ats-Tsani Min Al-Qiyadah (Mempersiapkan pemimpin lapis kedua dan generasi penerus). Namun, secara global telah tersistem dan terlaksana dengan baik.

\section{Referensi}

Abdul Gani Isa. (2013). Formalisasi Syari'at Islam di Aceh. Banda Aceh: IKAPI.

BandaAceh/IsiPiagamMadinah pasal 4/IsiPiagamMadinah_Arsip Armansyah.html diakses pada tanggal 20 maret 2017.

Cik Hasan Bisri. (2001). Penuntun Penyusunan Rencana Penelitian dan Penulisan Skripsi. Jakarta: Raja Grafindo Persada.

Djazuli. (2003). Fiqih Siyasah Implementasi Kemaslahatan Umat dalam Rambu-Rambu Syariah. Bandung: Kencana.

Eko Maulana. (2013). Kepemimpinan Integratif dalam konteks Good Governance. Jakarta: PT Multicerdas Publishing.

Firdaus. (2010). Peran ulama HUDA dalam politik pasca Orde Baru, rehab-rekon Aceh Pasca gempa dan tsunami, pasca MoU Helsinki hingga sekarang. Banda Aceh: Pusat Penelitian dan Penerbit UIN Ar-Raniry.

Herry Mohammad. (2008). 44 Teladan Kepemimpinan Muhammad. Jakarta: Gema Insani.

Khatib Pahlawan Kayo. (2005). Kepemimpinan Islam dan Dakwah. Jakarta: Amzah.

Muhammad Fathi. (2007). The Art of Leadership in Islam. Jakarta: Khalifa.

Muhammad Iqbal dan Amin Husein Nasution. (2014). Pemikiran Politik Islam. Jakarta : Kencana.

Taufiq Muhammad Asy-Syawi. (2013). Demokrasi atau Syura. Jakarta: Gema Insani. Veithzal Rivai \& Arviyan Arifin. (2009). Islamic Leadership. Jakarta: Bumi Aksara. Veithal Rivai. (2009). Kepemimpinan dan Perilaku Organisasi. Jakarta: Raja Grafindo. 